\title{
REPOSITIONING OF POSTSOCIALIST NARRATIVES OF NOWA HUTA AND DUNAÚJVÁROS
}

\author{
Katarzyna ZECHENTER \\ University College London
}

In June 2014, for just a few days, a statue of Lenin returned to Nowa Huta, close to the spot where once a huge monument of Lenin used to stand, dominating this socialist city visually (but not only so). ${ }^{1}$ The statue that 'returned' was small, less than half-a-meter tall and made of bright kitschy, greenish plastic: ${ }^{2}$ it was peeing in the same manner as the Manneken-Pis in Brussels. And yet the installation of the statue which proved popular with passers-by, was enough for two members of the main opposition Party in Poland, the Law and Justice Party, ${ }^{3}$ to file a complaint that this green 'pissing' Lenin 'promotes' Communism; and promoting Communism in post-1989 Poland is considered a crime. Even earlier, in 2008, representatives of the Law and Justice Party argued that 'any official commemoration of Nowa Huta's founding would be tantamount to proCommunist propaganda', ${ }^{4}$ suggesting to what degree Nowa Huta's past was still a thorny issue for many Poles.

How could the insignificant event during the summer festival of street art called ArtBoom 'awake the Polish demons' ${ }^{5}$ and cause such a heated response? In some postsocialist countries that are troubled by their own Communist legacy (Russia being a separate case $^{6}$ ) references to the Communist past can prove

1. I would like to thank Dr Thomas Lorman of UCL SSEES and Prof. Tom Burns of Emory University for their comments and suggestions during my work on this paper.

2. Neon green was being promoted as one of the most fashionable colours in summer 2014 and has an element of subversion through its high-visibility association.

3. Adam Kalita and Marcin Szymanski of the Law and Justice Party (PiS) believe that the statue of a pissing Lenin promotes Communism, which is illegal according to article 256 of the penal code: tvn24.pl/krakow,50/sikajacy-lenin-w-krakowie-pis-protestuje-zalozylismy-mu-prezerwatywe,438788.html

4. Katherine Lebow, Unifinished Utopia, Nowa Huta, Stalinism, and Polish Society, 1949-1956, Ithaca - London, Cornell University Press, 2013, p. 179.

5. rafalstanowski.natemat.pl/106037, 'sikajacy-lenin-wywolal-polskie-demony'

6. Svetlana Boym, The Future of Nostalgia, New York, Basic Books, 2001. 
popular, even attractive: suffice it to cite the example of the revival of a sausage in Lithuania named 'Soviet sausage' and promoted by large, Soviet-style advertisements. ${ }^{7}$ Why not in Poland? And specifically, why not in Nowa Huta?

This article investigates not only what such incidents suggest about the identity of postsocialist spaces 25 years after the collapse of Communism, but also, more importantly, what is necessary for a successful, i.e. generally acceptable and coherent, redefinition of the collective identity of a postsocialist space. 'Successful' in this context suggests such a narrative that emphasises the organic and national character of a space rather than its forced communist origin and its negative associations with the Soviet Union and Socialist Realism. It sets forth that the successful creation of a new identity through various forms of symbolism needs to correspond to the nation's collective identity within a larger process of reconfiguration of the Communist past. My analysis explores two such places: Nowa Huta in Poland or Dunaújváros in Hungary, while taking into account similarities between the histories of Poland and Hungary. ${ }^{8}$

I focus on various representations of these two well-known socialist cities because of the degree of similarity in their histories. Built in the 1950s to supply workers for enormous steel mills, and visually associated with socialism (and other socialist cities) through their monumental architecture which was meant to suggest a new culture and a break with the past, Nowa Huta and Dunaújváros share their transformation from being 'ugly' symbols of socialism to becoming symbols of opposition to the system (Dunaújváros in 1956 and Nowa Huta in 1980-1982 as well as during 1989), and later morphing into economically successful, or semi-successful, postsocialist towns with a strong innovative art scene. $^{9}$

My goal is to investigate whether, and to what degree, their popular success as seen through institutionalized and official narratives such as found in press articles, films, ${ }^{10} \mathrm{TV}$, theatre as well as non-institutionalized informal memory in social media ${ }^{11}$ such as private films found on Youtube, ${ }^{12}$ blogs, comments in

7. 'In 2004, Samsonas "Soviet" brands captured about $20 \%$ of the sausage market share in Lithuania'. Neringa Klumbyte, 'The Soviet Sausage Renaissance', American Anthropologist, 1, 2010, p. 27.

8. Ferenc Glatz (ed.), The Hungarians and Their Neighbors in Modern Times, New York, Columbia University Press, 1995.

9. Nowa Huta's youngest theatre Łaźnia Nowa is probably one of the most revolutionary theatres in Poland in its attempt to become an inhabited space that crosses various social boundaries.(laznianowa.pl/english). In Dunaújváros, the art scene includes artists such as Tamás Kaszás or Miklós Kiss who grew up there and whose works form a dialogue with political and social symbols;

see Maja and Reben Fowkes, 'Tamas Kaszas's Art Laboratory: Anticipating Collapse, Practicing Survival', translocal.org/pdfs/ArsH_2013_3_Fowkes.pdf; kissmiklos.com/

10. Including documentary films such as Papieros od prezydenta, dir. Grzegorz Kwinta, 1987.

11. Anna Karwiński, 'The role of contemporary media in creating an identity for a postsocialist city district: The case of Nowa Huta', in Media and Urban Space. Understanding, Investigating and Approaching Mediacity, Frank Eckardt (ed.), Berlin, Grank \& Timme, 2008.

12. Including music such as Rap $\mathrm{z}$ Nowej Huty (Rap music from Nowa Huta) youtube.com/watch? $=$ qgqAiDB6ovQ 
on-line newspapers or websites expressed over the last 25 years depends on reinterpreting their multi-layered narratives in accordance with the continuous repositioning of postsocialist national identity in these countries. I argue that the success of postsocialist spaces within growing globalization and diversification depends on aligning the cities' narratives with the essential aspects of their countries' national identity and thus further distancing them from Communism, which brought them to existence as an ideal example of socialist modernity. Given how elusive the concept of national identity is, this article simply assumes that natural identity is complex and multi-layered or, as Anthony D. Smith says, that it has various 'categories and roles' ${ }^{13}$ that are never constant and necessarily evolve over the years.

There is little doubt that in the last years, Dunaújváros and Nowa Huta have once again become a focus of attention (albeit to a different degree) ${ }^{14}$ as the number of books and articles about each city suggests, not to mention the range of artistic events and projects centred on and in them, be they feature and documentary films, exhibitions, concerts, or even operas. ${ }^{15}$ In the case of Nowa Huta, one might go so far as to speak of a boom in various narratives over the past ten years, as well as in projects to develop this part of Kraków: Nowa Huta was originally planned as a separate city, but in 1951, it was incorporated into Kraków and grew into the largest administrative unit in the Kraków conurbation.

From its very beginnings in 1949, Nowa Huta was seen through two opposite narratives: the official and the unofficial or the public (political, institutionalized) and the private, of which major parts have become known only recently. ${ }^{16}$ The official state narrative promoted a vision of Nowa Huta as a new city that was to be 'exemplary in its unconditional devotion to socialism', ${ }^{17}$ 'the pride of the nation', and 'the symbol of our great 6-year plan - the plan to industrialise our country - the plan to raise the standards of living for the working classes', ${ }^{18}$ but also to created a 'good life' for a modern worker. As a symbol of the new system that was completely to transform Polish society, ${ }^{19}$ the early interest in Nowa Huta was politically motivated, representing only the officially constructed

13. Anthony D. Smith, National and Other Identities, Reno, University of Nevada, 1991, p. 4.

14. Both in the Polish and foreign press: see, for example, The Guardian, 3 April 2011, 'New Europe, The Life of a Polish family', or Krisztina Fehérváry's extensive study Politics in Color and Concrete. Socialist Materialities and the Middle Class in Hungary, Bloomington, Indiana University Press, 2013.

15. Nowa Huta opera, within the project Projekt Nowa Huta. Dlaczego nie?! is based on Adam Ważyk's poem 'Poemat dla dorosłych' with music by Wu Hae, precursor of cross-over music in Poland. It is part of an ongoing project running since 2002 , with 32 concerts and film projects that attract thousands of spectators. krakownh.pl/wydarzenia/1/27.html

16. Maciej Miezian, Nowa Huta: socjalistyczna w formie, fascynująca w treści, Kraków,Bezdroża, 2004 or Nowa Huta. Księga uwolnionych tekstów, Kraków, Małopolski Instytut Kultury, 2005, which is the result of a project entitled 'nowa_huta.rtf (relacje, teksty, form)'.

17. Jan Kubik, The Power of Symbols Against the Symbols of Power. The Rise of Solidarity and the Fall of State Socialism in Poland, University Park, The Pennsylvania State University Press, 1994, p. 53.

18. Nowa Huta-duma narodu, Kraków, WKWFN, 1952, p. 5.

19. Zygmunt Bauman, 'Living without an alternative', The Political Quarterly 1, 1991, p. 35-44. 
memory. The official texts on Nowa Huta were thus anything but truthful, although some of them, such as Nowa Huta: duma narodu, purported to present the individual memories of its uneducated, but class-conscious inhabitants. Whether in newspaper articles, books, propaganda films, or on stamps and postcards, such texts deployed an officially idealised and sanitised version of reality, where 'Cracow was presented as a background to Nowa Huta, not the other way around, highlighting not only the implied importance of Nowa Huta, but also the transforming powers of Communism' ${ }^{20}$ Privately, in the memories of many of its inhabitants recorded after 1989 , not to mention the citizens of Kraków proper, ${ }^{21}$ the situation was vastly different, with Nowa Huta being sometimes no more than 'Sodom and Gomorrah, plague and malaria' ${ }^{22}$ Nowa Huta was seen as a brutish socialist city built 'against' the old and royal Kraków; a new city intended as a workers' town opposing the ostensibly conservative and anti-socialist Kraków. ${ }^{23}$

For many, including some scholars, Nowa Huta constituted a punishment for Kraków for voting 'no' in the June 1946 referendum, despite the fact that this is not historically accurate. ${ }^{24}$ The short-lived liberalization of the 1950 s enabled official journals for the first time to present some aspects of the unofficial narrative of Nowa Huta, which was vastly different from the official one, such as Ryszard Kapuściński's reportage 'This is also the truth about Nowa Huta' published in one of the leading newspapers, The Banner of Youth. ${ }^{25}$ With time, the social situation of the inhabitants improved and when in 1974 Bolesław Prażmowski published his pamphlet on Nowa Huta in a series Knowledge for All, he was able to acknowledge some problems such as the lack of infrastructure and pollution, but in general, he presented a picture of life in Nowa Huta that did not differ much from other cities. ${ }^{26}$ Works such as Stanisław Panek and Edmund

20. Katarzyna Zechenter, 'Evolving Narratives in Post-War Polish Literature: The Case of Nowa Huta (1950-2005)', SEER 4, 2007, p. 661.

21. The antagonism between Kraków and Nowa Huta has become proverbial: it originated initially as a response to the lawless behaviour of the young builders of Nowa Huta. See Barbara Klich-Kluczewska, 'Nowa Huta: skąd przychodzimy', in Moja Nowa Nowa. 1949-2009. Wystawa jubileuszowa, Kraków, Muzeum Historyczne Miasta Krakowa, 2009, p. 23.

22. Renata Radłowska, Nowohucka telenowela, Wołowiec, Czarne, 2008, p. 119.

23. Anne Applebaum, Iron Curtain. The Crushing of Eastern Europe 1944-1956, London, Penguin Books, 2012, p. 388; Jamie Stokes, 'Nowa Huta: Krakow's Brutal Brother?', 25 Feb. 2011: polishclubsf.org/Nowa\%20Huta.pdf

24. 'Folklore says that Kraków was singled out for retribution because of its unique resistance in the notorious 1946 People's Referendum. The plebiscite asked Poles to say "yes" or "no" to three proposals [...] Only in Kraków were opposition parties able to publish truthful returns [...]. The myth says that this embarrassment was punished by the construction of giant polluting chimneys looming over the city's ancient churches.' Jamie Stokes, 'Nowa Huta Krakow's Brutal Brother', 25 Feb 2011, Krakow Post, krakowpost.com/article/2509. See also: Bogumil Korombel in the film Miasto gniewu i nadziei: Nowa Huta. Czesc 1/2, 4:20; Franciszek Jóźwiak in the same film 7:36: youtube.com/watch?v=wVW5tgKpPcg; and Kubik: 'no churches were planned,' p. 53.

25. Ryszard Kapuścinski, 'To też jest prawda o Nowej Hucie', Sztandar Młodych, 1955, nr. 234.

26. Bolesław Prażmowski, Nowa Huta, Nauka dla Wszystkich 213, Warszawa, PWN, 1974. 
Piasecki's extensive anthropological study of more than 20,000 children ${ }^{27}$ created another positive, accurate and precise picture of Nowa Huta's inhabitants. The scholars concluded that despite initial differences, Nowa Huta in the 1970s did not differ from that of any other large city in Poland and was in many respects broadly typical of Communist Poland, although salaries in Nowa Huta were still among the highest in the country. ${ }^{28}$ Yet, despite such studies and the never-ending propaganda texts of the official press that focused on benefits, improvements and attempts to 'fulfil' the needs of the inhabitants of Nowa Huta, ${ }^{29}$ negative images of the city that were closer to the reality of the early $1950 \mathrm{~s}$ - those relating to, say, alcoholism ${ }^{30}$ or the high crime rate (major elements in the unofficial narrative) - did not go away. ${ }^{31}$ This negativism, although slightly mitigated by Andrzej Wajda's film on Nowa Huta, Man of Marble (1977), ${ }^{32}$ was still visible in 1993, when Marcin Świetlicki compared Nowa Huta to Gomorrah in his song 'Spat On' (Opluty) ${ }^{33}$ or in the fact that Nowa Huta's real estate prices are still the lowest in all of Kraków. ${ }^{34}$

The siting of a huge statue of Lenin in Nowa Huta in 1973 did not help endear the image of the city to many Poles, including some inhabitants of Nowa Huta itself. ${ }^{35}$ Some tried unsuccessfully to destroy the monument by blowing it up in April 1978. ${ }^{36}$ The fact that Nowa Huta was to be dissociated from Kraków's religious monuments (notably St. Mary's Basilica or the Wawel

27. Stanisław Panek, Edmund Piasecki, Integracja ludności w świetle badań antropologicznych. Integration of population of Nowa Huta in the Light of Anthropological Data, Wrocław, PAN, 1971, p. 237.

28. Michael D. Kennedy, Professionals, Power and Solidarity in Poland: A Critical Sociology of A Soviettype Society, Cambridge, Cambridge University Press, 2008.

29. Nowa Huta, Trybuna Robotnicza, 17 June 1974 or the text around the erection of Lenin's monument in Nowa Huta on 22 April 1973. Polskie Radio: polskieradio.p1/39/156/Artykul/826361/

30. The first Nowa Huta newspaper, Budujemy socjalizm (We are Building Socialism), often wrote about alcoholism among the young 'builders'. Jakub Bladek, in Moja Nowa Huta. 1949-2009, Wystawa jubileuszowa, K. Jurewicz (ed.), Kraków, Muzeum Historyczne Miasta Krakowa 2009, p. 175. Jan Franczyk, 'Mieszkańcy Huty nie narzekają', 1 Jan 2013, radiokrakow.pl/www/index.nsf/ID/KORI-9C3GZA. In August 1958, The New York Times wrote: 'This is Poland's newest town, a raw and youthful town, a town that works hard, drinks too much vodka and eats too much sausage, boasts of a million tons of steel and fifteen musicians and is not quite sure whether it is the pride of the nation or its stepchild', The New York Times, A. M. Rosenthal, 1 Aug. 1958 , p. 15.

31. Leszek L. Sibila, Kryptonim Gigant. Dzieje nowohuckiego kombinatu w latach 1949-1958, Kraków, Muzeum Historyczne Miasta Krakowa, 2008, p. 25; Katherina Lebow, Unfinished Utopia: Nowa Huta, Stalinism and Polish society, Ithaca - New York, Cornell University Press, 2013, p.181.

32. The sequel of Man of Marble, Man of Iron also directed by Andrzej Wajda in 1981 ties Nowa Huta to an even more critical approach to the Communist regime. Lisa DiCaprio, 'Man of Marble', 'Man of Iron. Polish Film and Politics', Jump Cut. Review of Contemporary Media, 27, 1982, p. 7-12, ejumpcut.org/archive/onlinessays/JC27folder/ManMarbleIron.html

33. Marcin Świetlicki, 'Opluty, Kraków i Nowa Huta - Sodoma z Gomorą,/ z Sodomy do Gomory jedzie się tramwajem. /Chodzę po mieście,/ Chodzę po mieście/ Opluty.' teksty.org/swietliki,opluty,tekst-piosenki

34. Kinga Pozniak, 'Generations of memory in the "model socialist town" of Nowa Huta, Poland', Focaal, 66, 2013, p. 59.

35. polskieradio.pl/39/156/Artykul/826361/

36. Moja Nowa Huta. 1949-2009. Wystawa jubileuszowa. Kraków, Muzeum Historyczne Miasta Krakowa, 2009 , p. 244. 
Cathedral) and related traditional narratives, which carried a huge symbolic load in Polish history and national identity, further alienated Nowa Huta. Here is a case in point: the medal minted to commemorate the erection of the Lenin monument in Nowa Huta was adorned with a poorly-known image of the Barbican in Kraków (the fortified outpost that used to be connected to the city walls), and not with some other easily recognizable symbol.

The second contrast between official and private narratives in Nowa Huta is visible through the presentation of religion, or rather its institutionalized expression. There had to be no connection between Nowa Huta and religion any more than in the general case of any socialist city. ${ }^{37}$ The original, but unofficial plans did include the construction of a church, although Bolesław Bierut, the then president of Poland, 'wanted no church in Nowa Huta, but he wanted a "tower" because "it might remind people of a church", ${ }^{38}$ There were, however, older churches near Nowa Huta, especially a Cistercian Abbey in the village of Mogiła and at Bieńczyce, but they quickly became too small for Nowa Huta's rapidly growing population. Although the authorities agreed in 1956 to build a new church, they also mounted countless obstacles and later decided to use the presumed site for a much-needed primary school. ${ }^{39}$ The riots that broke out in April 1960 to defend a cross erected where the church was to have be located became known as the Battle for the Cross. ${ }^{40}$ Although passed over in complete silence in the official Polish press, the riots went on for several days and resulted not only in the destruction by fire of some party buildings in Nowa Huta (Dzielnicowa Rada Narodowa), but also in the deaths of some of the protestors. ${ }^{41}$ The events became known outside Poland through Radio Free Europe and an article in The New York Times. ${ }^{42}$ Eventually, however, the supressed stories of the 'struggle for the Cross' became an essential part of Nowa Huta's unofficial communicative memory and of the city's new identity. ${ }^{43}$

37. Religion During and After Communism, M. Tomka, P. M. Zulehner (eds.), Concilium 2000/3, London, SCM Press, 2000, p. 5-11.

38. Lebow, p. 30. Some sources claim that 'the original plans for Nowa Huta included a site for a grand church and the Union of Polish Architects held a competition to find a winning design in the 1950s', Jamie Stokes, 'Nowa Huta: Krakow's Brutal Brother', 25 Feb. 2011. Jan Kubik states that in Nowa Huta no churches were planned for the city, p. 53; krakowpost.com/article/2509.

39 Antoni Mroczka, former 1st Secretary of the PZPR in Nowa Huta, [In the film:] Miasto gniewu $i$ nadziei, Część 1/2, 29:11, youtube.com/watch?v=wVW5tgKpPcg.

40. Anna Zechenter, Pod czerwonq okupacja. Adam Macedoński w rozmowie z Annq Zechenter, Kraków, Wydawnictwo A A, 2013; Jerzy Ridan, 'Walka o krzyż w Nowej Hucie', Karta. Kwartalnik Historyczny, 21 1997, p. 119-141.

41. Malik speaks of 493 arrests, 17 people hospitalised after being shot by the people's militia (milicja), 87 imprisoned, and 119 fined, Andrzej Malik, 'Nie można oddzielić krzyża od ludzkiej pracy...', Komisja Robotnicza Hutnikow NSZZ Solidarność Huty im. Lenina (sierpień 1980-grudzień 1981), Warszawa, IPN, 2013, p. 22-23.

42. The New York Times, May 15, 1960, 'Gomulka Scores Riots; Visits Nowa Huta and Assails "Hooligans" on Church Issue'.

43. Jan Franczyk, Na fundamencie krzyża: kościól katolicki w Nowej Hucie w latach 1949-1989, Kraków, Rafael, 2004. 
By the mid-1970s the two parishes of Mogiła and Bieńczyce had over 200,000 parishioners. Cardinal Karol Wojtyła (later Pope John Paul II) began efforts to obtain a permit to build the new church that he finally consecrated on 15 May 1977, ten years after construction began. ${ }^{44}$ Such a long campaign to build a church in this iconic socialist city despite various and multiple obstacles allowed John Paul II to present Nowa Huta as 'built on the foundations of the Cross of Jesus,' thus adding a Christian dimension to Nowa Huta narratives by connecting the city with an important aspect of what has been seen, since the times of the partitions (both within Poland and abroad), as the essence of traditional Polish identity - Catholicism. ${ }^{45}$

This rift between official and unofficial narratives about Nowa Huta is also prominent within the narrative of the 1980s struggle for Poland's independence. However, at the very beginning of the Solidarity movement in the summer of 1980 it was not obvious that Nowa Huta would go on strike alongside other Polish factories, most notably the Lenin Shipyard in Gdańsk, which had already gone on strike in August that year. The oft-quoted scurrilous saying of the period, 'the people of Kraków are fu..ers, not Poles ('Krakowiacy ch... nie rodacy'), ${ }^{46}$ and the fact that Nowa Huta had a much higher percentage of its workforce who were Party members (up to $25 \%)^{47}$ clearly suggest the tensions over Nowa Huta's stance at that time. Jadwiga Staniszkis concludes that in general the 'process of identity formation among the workers was slow and tedious', ${ }^{48}$ but in the summer of 1980, in Nowa Huta, this process was slower than, for instance, in the Gdańsk shipyard, as evidenced by the above-mentioned saying.

Eventually, however, $90 \%$ of the workers at the Lenin steel plant joined Solidarity, ${ }^{49}$ and The Workers' Committee of the Steel Industry became the strongest organization in the regional structure of the independent trade union, which resulted in 'the work of rebuilding national identity, weakened by the communist government'. ${ }^{50}$ The struggle became clearly visible during the period of martial law, when the steelworkers and around 150 students from AGH University of Science and Technology ${ }^{51}$ barricaded themselves in the

44. Jerzy Aleksander Karnasiewicz, Nowa Huta. Okruchy życia i meandry historii. The crumbs of life and the meandering of history, Kraków, Wydawnictwo Towarzystwa Słowaków w Polsce, 2003, p. 39; Marian Kordaszewski, 'Arka Pana.' Przewodnik. Historia i symbolika, Kraków, Wydawnictwo Benedyktynów, 1995.

45. 'A golden opportunity,' Special report: Poland, The Economist, June 28, 2014, p. 10-11.

46. Jaroslaw Szarek, 'Solidarna Nowa Huta 1980-1989,' in U progu wolności. Nowa Huta w latach 19801989, Kraków, Muzeum Historyczne Miasta Krakowa, 2005, p. 10. Often only the polite version of the saying is quoted: 'Krakowiacy nie Polacy - czemu nie strajkujecie,' in: Maciej Miezian, Leszek Sibilia, 'Kalendarium Nowej Huty'; Futuryzmy miast przemystowych. 100 Lat Wolfsburga i Nowej Huty, Kraków, Korporacja Ha!art 2007 , p. 62.

47. Szarek, 'Solidarna Nowa Huta 1980-1989...', p. 10.

48. Jadwiga Staniszkis, Ontologia socializmu, Warsaw, Plus, 1989, p. 117.

49. Malik, 'Nie można oddzielić krzyża od ludzkiej pracy...', p. 296.

50. Szarek, ‘Solidarna Nowa Huta 1980-1989...', p. 12.

51. Marek Domagała, Relacja,

encyklopedia-solidarnosci.pl/wiki/index.php?title=L00108_Marek_Domaga\%C5\%82a 
plant. The occupation ended only on 16 December because of the overwhelming presence of 2,000 soldiers and 2,150 militiamen, who broke down the two main entrances to the plant, while the workers had made the conscious decision to use only passive resistance. ${ }^{52}$ As Jerzy Sadecki concluded: 'the city that was built on the ideology of soc-realism rejected this ideology completely'. ${ }^{53}$ After the milicja killed one young steelworker, Bogdan Włosik, the demonstrations and street fights with police became bloody and widespread. ${ }^{54}$ They also became widely known through photos, especially one of the most famous photos of the martial law period taken by Stanisław Markowski in Nowa Huta on 13 October $1982,{ }^{55}$ showing three young men running holding a large Polish flag. ${ }^{56}$

After 1989, 'the Struggle for the Cross' and 'the Struggle for Freedom', these two aspects of Nowa Huta's unofficial, private memory that had been suppressed by the communist system, came to form the very basis of Nowa Huta's new identity now based on Poland's struggle with Communism. More importantly, however, the rejection of the official narrative represented a successful attempt to insert Nowa Huta into the traditional discourses of Polish history and national identity, within its essential elements of struggle for independence and struggle for religion. Thus, by fully rejecting Communism and accepting 'traditional' Polish values such as 'faith and fatherland', ${ }^{57}$ the new Nowa Huta narrative consolidated the link of the city with what has been seen as the core of Polish identity over the last two hundred years. Nowa Huta was reborn, now not as a symbol of socialism, but a hero of opposition to socialism.

The post-1989 narratives of the city of Dunaújváros follow a different path from Nowa Huta, despite the fact that similarly to Nowa Huta, Dunaújváros had been constructed as a model socialist town during the period of forced industrialization, with concentration on heavy industry, massive collectivization, and the absence of religion, although for the majority of workers this was difficult to accept. ${ }^{58}$ It was built and later inhabited by uneducated farmers who came

52. Malik, 'Nie można oddzielić krzyża od ludzkiej pracy...', p. 286-287.

53. Jerzy Sadecki, Ziarna gniewu, Paris, Éditions Spotkania, 1989, p. 7. Quotation translated by K. Zechenter.

54. Bogdan Włosik was killed by police near the Arka Pana church on 13 October 1982. Stan wojenny w Małopolsce. Relacje i dokumenty, Zbigniew Solak, Jarosław Szarek, Henryk Głębocki, Jolanta Nowak, Adam Roliński (eds.), Kraków, IPN, 2005, p. 161-173.

55. Szarek, 'Solidarna Nowa Huta 1980-1989...', p. 8.

56.google.com/search?q=nowa+huta+stan+wojenny+markowski\&client=firefox-a\&hs=KVw\&rls=org.m ozilla:en-US:official\&channel=sb\&source $=\operatorname{lnms\& tbm=isch\& sa=X\& ei=DUfCU4jKKcKkyATdoYHQAw\& v}$ ed $=0$ CAgQ_AUoAQ\&biw $=1131 \&$ bih $=574 \#$ facrc $=$ \&imgdii $=$ \&imgrc $=$ p35r-xVds2prsM\%253A\%3BEiwITuXtXJCiHM\%3Bhttp\%253A\%252F\%252 Fwww.wszechnica.solidarnosc.org.p1\%252Fwpcontent\%252Fuploads\%252F2010\%252F10\%252F10-Markowski-N.Huta-pod-Ark\%2525C4\%2525851510-1982-w.jpg\%3Bhttp\%253A\%252F\%252Fwww.wszechnica.solidarnosc.org.pl\%252F\%253Fpage_id\%25 3D2139\%3B960\%3B697

57. Brian Porter-Szücs, Faith and Fatherland. Catholicism, Modernity, and Poland, New York, Oxford University Press, 2011.

58. Fehérváry, Politics in Color and Concrete..., p. 71. Similarly to Nowa Huta, the only churches in Dunaújváros were in the old village but the 'churchgoing population was negligible'. Fehérváry, Politics in 
from the countryside ${ }^{59}$ next to an old village, Dunapentele. The construction of the city began in 1950, and despite many initial problems, soon the city boasted, unlike Nowa Huta, a successful infrastructure such as efficient transport, good housing, and large schools. ${ }^{60}$ During the first years, the official narrative was omnipresent, with daily radio reports, speeches, and more than twenty newsreels and short films publicising the modernity of the new city. ${ }^{61}$ In the unofficial narratives, it was, however, regarded as 'the ugliest city in Hungary, the muchpublicized exemplar of Soviet city planning, emblematic of Hungary's subordination to the Soviet Union'. ${ }^{62}$ Two years after construction began, on 4 April 1951, the city took the name of Sztálinváros, parallelling Stalingrad and thus joining other Stalin cities in Central Europe: Stalin (Varna, Bulgaria), Stalinstadt (Eisenhüttenstadt, Germany) and Oraşul Stalin (Braşov, Romania). ${ }^{63}$

During the 1956 Hungarian Revolution, the socialist town rejected its official name and reclaimed the name of Dunapentele. Revolutionary organizations and independent radio ${ }^{64}$ were set up in the city on 28 October 1956 (and in other towns outside Budapest as well) while the city tried to defend itself from the Soviet Army, but on 7 November 1956, martial law was declared and the city pacified. ${ }^{65}$ It also had to return to its Communist name. ${ }^{66}$ Only five years later, after normalization and destalinization, was the city officially renamed Dunaújváros ${ }^{67}$ (New City on the Danube). It continued to grow, with the majority of families working in the steel mill. ${ }^{68}$ The city was modern and comfortable, and its workers well paid, so 'the socialist model seemed to work,

Color and Concrete..., p. 33-34. After 1996, a Catholic cathedral and a Lutheran-Calvinist church were built: the city has also an active Mormon congregation.

59. Dunaújváros 1967, Dunaújváros, 1968 (no author, no publisher given).

60 . The city was seen as 'a city' mostly by peasants who came from the countryside but could not, in any way, be compared to Budapest with its sophisticated urban dwellers. In the press, however, it was referred to as the City of Youth because of the age of its inhabitants. See Sándor Horváth, A kapu és a határ, Budapest: MTA Történettudományi Intézete, 2004. In the 1960s, Dunaújváros had the largest primary school in Central Europe, the Endre Ságvári Primary School:

visitoruk.com/Coventry/dunaujvaros-in-hungary-C1206-L22097.html.

61. Fehérváry, Politics in Color and Concrete..., p. 71.

62. Id., p. 2.

63. Mariusz Czepczyński, Cultural Landscapes of Post-Socialist Cities. Representation of Powers and Needs, Aldershot, Ashgate, 2008, p. 78.

64. The revolutionary radio, Pentele Rákóczi Radio, continued to transmit from Dunapentele until the end of the revolution from different cars so it would not be found out by the Soviet forces. jakd.hu/index.php? $\mathrm{p}=$ sztalinvaros

65. National Széchényi Library, 1956 Institute And Oral History Archive. rev.hu/history_of_56/ora3/index.htm

66. Fehérváry, Politics in Color and Concrete..., p. 74.

67. In 1960 and 1961 a few cities named after Stalin changed their names: Stalinabad changed to Dushanbe (Tajikistan), Stalingrad to Volgograd (Russia), Staliniri to Tshinavali (Georgia), Stalinstadt to Eisenhüttenstadt (East Germany) or Stalino to Donetsk (Ukraine). Katowice was named Stalinogród on 9 March 1953 after Stalin's death, but in 1956 the original name was restored.

68. Fehérváry, Politics in Color and Concrete..., p. 74. 
and to work well in Dunaújváros' ${ }^{69}$ In general, during this period in Hungarian history, in the 1960s and 1970s, the quality of life grew rapidly under the leadership of János Kádár. The improvement in 'material prosperity relative to other Soviet bloc countries was made possible by what became known as "goulash communism," or a combination of central planning with economic reforms and a high tolerance for a second or informal economy'. ${ }^{70}$

Today, after serious economic difficulties during the early period of transition after the collapse of Communism ${ }^{71}$ and the economic restructuring that hit all post-Communist countries hard, Dunaújváros is again a busy city of almost 50,000 inhabitants, ${ }^{72}$ with a large part of the population (7,500 workers) still working in the steel industry, although since 2007, people were also employed in the Hankook tyre factory (2,000 workers), the seventh largest tyre producer in the world; in a paper mill, the Hamburger Hungaria $\mathrm{Kft}$, which employs 300 workers; and in the country's biggest concrete prefabricator company, Ferrobeton Zrt, employing around 1,000 workers. All this results in the fact that Dunaújváros has a lower unemployment rate than the rest of Hungary (similar to Nowa Huta) ${ }^{73}$ although the success of Hungarian economic reform is another matter. ${ }^{74}$ Since 1953 the city also features the College of Dunaújváros (Dunaújvárosi Föiskola), now prosperous and successful with more than 3,500 students (many of them international) and a large new European Campus. ${ }^{75}$ The College aspires to be a centre of intellectual innovation, and its reputation is enhanced by its own publishing house and by a large research project on conflicts in post- 1989 Hungary. ${ }^{76}$

Nowadays the city rarely appears in international media except in the business pages, but its success is visible through information about young Dunaújváros photographers ${ }^{77}$ or the 80 -strong amateur choir from Dunaújváros performing in the prestigious Carnegie Hall in New York in January $2014^{78}$ or the works of an internationally known artist and designer, Miklós Kiss. ${ }^{79}$

69. I. András and M. Molnár, 'Multinational Companies in a post-Socialist Society: Conflicts of Intercultural Relationships,' in Confligo: Conflict in a Society in Transition, B. A. Szegál, I. András (eds.), Dunaújváros, Dunaújváros College Press, 2011, p. 165.

70. Fehérváry, Politics in Color and Concrete..., p. 4.

71. John Tagliabue, 'Hungary, on NATO Conflict's Front Line, Feels a Sense of Anxiety', The New York Times, May 2, 1999.

72. The population of Dunaújváros decreased from 59,000 in 1990 to around 50,000 in 2013.

73. András and Molnár, 'Multinational Companies in a post-Socialist Society...', p. 165; Lebow, Unifinished Utopia, Nowa Huta..., p. 179.

74. Katherine Cornell Gorka, Drowning the Tiger: The Failure of Hungarian Economic Reform 19892009, CRCE Briefing Paper, London, Centre for Research into Post Communist Economies, 2010.

75. duf.hu/english.

76. András and Molnár, 'Multinational Companies in a post-Socialist Society...', p. 169.

77. 'Ghosts of the past: photo fair looks to ex-Soviet east', The Independent, 20 Nov. 2010.

78. gofundme.com/HungariansinCarnegieHall

79. en.wikipedia.org/wiki/Mikl\%C3\%B3s_Kiss; kissmiklos.com/ 
Unlike Nowa Huta, the modern Dunaújváros narratives emphasise not the struggle with the Communist system, but rather the metamorphosis and mutability of the old Dunapentele (the original village next to which the Communist city was built) through its incarnations as Sztálinváros and Dunaújváros. ${ }^{80}$ The focus is not on the break from Communism, but rather on the continuous transformation of the city since Roman times, exemplified by various narratives arguing, for instance, that the location of the city was to a high degree not a communist decision, but an organic result of the desire of Hungarian nineteenth-century patriots and statesmen, who wanted to develop the country and boost its economy through heavy industry. One of the websites of the steel works in Dunaújváros calls Count István Széchenyi 'the initiator' and quotes his letter of 5 April 1842 to the English engineer William Tierney Clark, the designer of the Széchenyi Chain Bridge across the Danube in Budapest, stating that he doubts that 'anything could be more important in a developing country on the two sides of the River Danube than building good iron factories' ${ }^{81}$ Considering that Széchenyi 'has been almost canonised in his native Hungary' ${ }^{82}$ because of his role in modernising the country and because his name carries considerable weight even among the young generation, ${ }^{83}$ adding Széchenyi's name to the history of Dunaújváros suggests greater inclusion of the city's narrative into national narratives. The seeds of this narrative emphasising Dunaújváros's organic character were visible even under Communism, when the residents 'fiercely defended the town's credentials as a modern, Hungarian city - the successful realization of a centuries-long dream that Hungary would one day produce its own steel' while at the same time being aware of 'the stigma' that they come from a city symbolising 'Hungary's subordination to the Soviet Union'. ${ }^{84}$

To some degree, the narrative of the transformation of the city had already been admitted by the communists, who could not ignore the existence of the Roman settlement Intercisa ${ }^{85}$ in this place as well as that of the medieval village: in a highly propagandistic book on Sztálinváros from 1959, the emphasis is not only on the benefits of the new socialist city in comparison with the backwardness of the countryside, but also on the Roman past, highlighted by photographs of Roman artefacts. ${ }^{86}$ The new, ${ }^{87}$ post-1989 coat of arms of

80. jakd.hu/index.php? $=$ linktar\&dir $=10$

81. ipari.bzlogi.hu/linkelt_dokumentumok/vaskultura_konferencia/tablo/dunaujvaros_en.pdf

82. P. Vaci Sandor, 'William Tierney Clark and the Buda-Pesth chain bridge', Proceedings of the ICE Engineering History and Heritage, 2, 2011 , p. 109.

83. György Csepeli, National Identity in Contemporary Hungary, trans. M. D. Fenyo, Boulder, Atlantic Research and Publications, 1997, p. 149.

84. Fehérváry, Politics in Color and Concrete..., p. 2.

85. Visy Zsolt, The ripa Pannonica in Hungary, Budapest, Akademiai Kiadó, 2003.

86. Sztálinváros, Miskolc, Tatabánya: városépitésünk fejlődése, A. Sós, F. Kálmán (eds.), Budapest, Müszaki Könyvkiadó, 1959, p. 27-34.

87. duol.hu/hirek/pentele-leendo-cimere- 1600872 
Dunaújváros also supports the narrative of transformation, as it incorporates the Roman past (the image of a column), a lamb with a cross symbolizing the original mediaeval settlement, and the silver-and-red-chequered fields representing metallurgy and the organized, planned character of the city. Some scholars argue that such an acceptance of the Communist past, from the economic point of view, might be the result of the high standard of living in Dunaújváros, which was heavily subsidised during Communism ${ }^{88}$ and now offers many new employment opportunities, unlike Nowa Huta, which despite some efforts to economic revitalization, is still struggling. Andras and Molnar thus argue that the particular effect of the 'happy Socialist time' proves to be long-lasting in Dunaújváros. For twenty years since the transition began, it is mostly Socialist party candidates who won seats in the local assembly and national Parliament. ${ }^{89}$

In post-1989 narratives, this mutability is emphasized even further through non-institutionalized narratives. ${ }^{90}$ Miklós Kiss, for instance, a young artist from Dunaújváros, received a prize for his black-and-white print on canvas entitled Metamorphose of Dunaújváros, ${ }^{91}$ in which all names of Dunaújváros: Intercisa (the Roman settlement and military post from the first to the fifth centuries ${ }^{92}$ ), Pentele (the original village), Dunapentele (medieval to 1951), Sztálinváros (1951-1961) and Dunaújváros (1961-), mutate into one another, thus visually incorporating the Communist, even Stalinist history of Dunaújváros, yet without emphasizing its importance. (fig. 30)

Rasa Balockaite argues that planned socialist towns adopt various strategies to deal with their 'unwanted past', namely 'ironic remembrance of the socialist past alongside ironic mimicry of the West, private nostalgia of the socialist past and public denial of its existence, and, finally, the use of de-ideologized images of green, young towns while other symbolic recourses are absent, insufficient or considered illegitimate'. ${ }^{93}$ While until very recently Nowa Huta's narratives follow with some exceptions the path of rejection of its past, ${ }^{94}$ Dunaújváros's narratives stress organic change, emphasizing not just the city's Roman past, but more importantly, its roots in the ideals of nineteenth-century Hungarian reformists such as Széchenyi, and thus presenting the Communist period only

88. Although towns like Dunaújváros are inhabited by no more than $4 \%$ of Hungary's population, they nonetheless used around $30 \%$ of the energy resources (1986). Pál Germuska, Indusztria büvöletében: Fejesztéspolitika és a szocialista városok, Budapest, 1956-os Intézet, 2004.

89. Andras, Molnar, Confligo, p. 165.

90. See for instance: dunaujvaros.com/varostortenet or jakd.hu/

91. kissmiklos.com/metamorphose-of-dunaujvaros

92. Thomas S. Burns, Rome and the Barbarians, 100 B.C.- A.D.400, Baltimore - London, The Johns Hopkins University Press, 2003, p. 221-222.

93. Balockaite, Rasa, 'Coping with the Unwanted Past in Planned Socialist Towns: Visaginas, Tychy, and Nowa Huta', Slovo 1, 2012, p. 59.

94. Jacek Salwiński, Leszek J. Sibilia, Nowa Huta przyszłość $i$ wizja. Studium Muzeum Rozproszonego, Kraków, Muzeum Historyczne Miasta Krakowa, 2005. 
as a part of the city's identity while also emphasizing the city's smart design, which, for instance, separated the steel mill from the city with a green belt. ${ }^{95}$

The narratives about Nowa Huta and Dunaújváros suggest that the symbolic success of postsocialist cities depends on aligning the city's identity with the general prevalent understanding of national identity. As László argues, all kinds of texts, including those derived from individual memories, contribute to the construction of national identity. ${ }^{96}$ Identity is, after all, a complex issue that has divided philosophers, psychologists, and historians. In Eastern Europe the issue is made more complex by growing European integration since the Treaty of Maastricht in 1992, although some scholars claim that the feeling of being European has been overestimated because it 'has always been enmeshed with national agendas'. ${ }^{97}$ As Maurice Halbwachs has argued, nations, people, and spaces have their complex identities, connected through continuously re-shaped collective memory. ${ }^{98}$ Furthermore, as Jan Assmann maintains, communicative (that is unstructured, 'everyday' memory that is shared and exchanged within a social group over a time span of around 80 years) and cultural memory (the way a society ensures its collective identity is maintained 'through cultural formations (texts, rites, monuments)' also contribute to their elaboration. ${ }^{99}$

The contradictory narratives of Nowa Huta and the almost complete rejection of its socialist past indicate that modern Poles still do not feel comfortable with Nowa Huta's past despite various initiatives to change this approach and despite visual evidence suggesting that Nowa Huta's past included 'normality' and not just struggle against the system. ${ }^{100}$ Some texts on the region attempt to suggest that the creation of the city was, in fact, mostly an eradication of a successful agricultural region for political gains. ${ }^{101}$ Even when the narrative is not directly connected with Communism but only with Nowa Huta's individual lives, often the past is presented as a problem and a corruptive force. Two narratives, one from 1952 and the other from 2008, serve as a case in point. Nowa Huta: duma narodu from 1952 presents stories of various people who built Nowa Huta.

95. 'Dunaújváros városképére jellemzőek a tágas zöld területek, virágos parkok, amelyek jól tompítják az egyes épületek monumentalitását. Az ipari területeket is erdős részek választják el a várostól. A természetes környezet jelenléte biztosítja a település ökológiai egyensúlyát, ,in dunaujvaros.com/varostortenet

96. János László, Historical Tales and National Identity: An introduction to Narrative Social Psychology, London, Routledge, 2014, p. 163.

97. John Hutchinson, 'Enduring nations and the illusion of European integration', Europeanisation, National Identities and Migration. Changes in Boundary Construction Between Western and Eastern Europe, W. Spohn, A. Triandafyllidou (eds), London, Routledge, 2003, p. 36.

98. Maurice Halbwachs, On Collective Memory, Chicago, The University of Chicago Press, 1992.

99. Jan Assmann, 'Collective Memory and Cultural Identity', trans. J. Czaplicka, New German Critique 65, 1995, p. 125-133.

100. Robert Kosieradzki, Nowa Huta. Lata sześcdziesiąte i siedemdziesiq̨te, Kraków, Nowohuckie Centrum Kultury, 2006; Wiktor Pental, Nowa Huta. Lata pięćdziesiąte, Kraków, Nowohuckie Centrum Kultury 2009. See also nh.pl/ludzie.htm, nh.pl/teatr.htm

101. Jerzy Aleksander Karnasiewicz, Nowa Huta. Okruchy życia i meandry historii. The Crumbs of Life and the Meandering of History, Kraków, Towarzystwo Słowaków w Polsce, 2003. 
Although the book includes stories of people connected with Nowa Huta, its obligatory narrative allows only one reading: through poverty and persecution in pre-war Poland to the happiness of a communist Nowa Huta, where the workers are building 'the happy tomorrow'. ${ }^{102}$ The style of this collection of stories employs vulgar simplifications, direct approach and poor vocabulary based on propaganda clichés, while strongly resembling the formulaic nineteenth-century stories for the uneducated peasantry. The readership of such stories was guaranteed anyway, but the authors tried to attract the readers through inclusion of elements of fairy tales ('How Gustek become a smith'), ${ }^{103}$ humour ('Freedom of Staszek Talarczyk' 104) and names of characters typical of Polish peasantry. In 2008, a young journalist, Renata Radłowska, published her collection of short stories about Nowa Huta entitled 'Nowa Huta soap opera.' Unlike the 1952 publication that presented Nowa Huta in glowing terms, Radłowska presents a different reality of Nowa Huta, but in a style recalling that of Nowa Huta: duma narodu: her stories of various individuals who worked in Nowa Huta 'undo' the happiness promised by Nowa Huta: duma narodu. At times naïve and melodramatic, as any proper soap opera should be, Radłowska's stories use the same simple language of uneducated speakers from Nowa Huta: duma narodu, but this time emphasising the unhappy lives of former steelworkers: their happiness is equated with their youth and not with the socialist city.

Interestingly, Radłowska's stories belong to a growing number of narratives about average individuals from Nowa Huta who were not influential in creating the city, but worked there nonetheless, yet were ignored by official past narratives, because of their lack of appropriate political engagement. They are beginning to be seen as those who might bring 'a new meaning to this space', a starting point in constructing a new identity for Nowa Huta in the twenty-first century. ${ }^{105}$ This process of focusing on Nowa Huta through individual understandings of the place using interviews, family photographs or short, private films is becoming more pronounced and includes other narratives next to the national narratives of struggles and religion. ${ }^{106}$ This process might have been initiated by a large exhibition on Nowa Huta which took place in 2009 in Kraków and whose title My Nowa Huta strongly focuses on the individual, not the social perspective. A new interactive website, entitled NHpedia, also emphasises individual forms of memory of the place, which, with time, will affect Nowa Huta's identity. ${ }^{107}$

Dunaújváros narratives, in contrast, suggest that the city's past might be accepted because, despite being built by communists, it can be presented as a

102. Nowa Huta: duma narodu, p. 55.

103. Id., p. 59

104. Id., p. 63.

105. Nowa Huta. Księga uwolnionych tekstów, Kraków, Małopolski Instytut Kultury, 2000.

106. Moja Nowa Huta, p. 6.

107. nhpedia.pl 
part of Hungary's national history, an ultimate result of modernisation that started in the nineteenth century, not just a Soviet imposition. ${ }^{108}$ At the same time, the continuous transformation of the narratives of Dunaújváros resonates well with the rapid changes in European social and cultural landscapes after 1989 and growing globalisation, while still emphasizing that 'Hungary is a country where questions of national identity' are highly influential, especially in politics. ${ }^{109}$ Hungarian national identity is strongly tied to the Hungarian language, to culture, and to certain territories (some of them evoked in the Hungarian national anthem), which Hungarians call Historic Hungary (formerly the Kingdom of Hungary): Dunaújváros simply plays no role in such understanding of identity, which might explain why its Communist past does not arouse such hostility as it does in Nowa Huta. ${ }^{110}$ Furthermore, as the current far-right political parties in Hungary focus more on their resentment towards those who they perceive as Others (e.g. Romani, Jews, Muslims) or the 'threat' of the multicultural EU, their interest in honest discussion about Hungary's past, including WWII or Communism, is weaker. ${ }^{111}$ So strengthening of national identity is accomplished more by the rejection of other groups that an in-depth analysis of Hungary's own past.

The traumas that Poland and Hungary underwent in the twentieth century can thus be read differently through the narratives of these two socialist cities. Nowa Huta's narrative suggests the strength of Polish attachment to the romantic concept of national struggle, ${ }^{112}$ because 'Poles inject communism [...] into a long narrative vein of conquest, occupation, and oppression by powerful neigbors'. ${ }^{113}$ This attitude towards collective victimhood, however, might be changing, as suggested by the approach towards Nowa Huta of the youngest generation born after $1989,{ }^{114}$ whose attitude towards national mythology is more critical than their parents. This is supported by research that emphasises the generational aspect of various narratives of repression and resistance but, at the same times, exhibits pride in Nowa Huta's history. ${ }^{115}$

108. Maya Nadkarni, 'The Master's Voice: Authenticity, Nostalgia, and the Refusal of Irony in Postsocialist Hungary', Social Identities, 5, 2007, p. 611-626.

109. Agnes Batory, 'Kin-state identity in the European context: citizenship, nationalism and constitutionalism in Hungary', Nations and Nationalism, 1, 2010, p. 45.

110. George W. White, Nationalism and Territory: Constructing Group Identity in Southeastern Europe, Boston, Rowman and Littlefield, 2000, p. 67-118.

111. Katalin Halasz, 'The Rise of the Radical Right in Europe and the Case of Hungary: Gypsy crime' defines national identity', Development, 4, 2009, p. 490. gla.ac.uk/0t4/crcees/files/summerschool/readings/school

112. Alexandra Wangler, Rethinking History, Reframing Identity. Memory, Generations, and the Dynamics of National Identity in Poland, Bremen, Springer, 2012.

113. Geneviève Zubrzycki, 'Polish Mythology and The Traps of Messianic Martyrology', [In:] National Myths. Constructed Pasts, Contested Presents, Gérard Bouchard (ed.), London, Routlege, 2013, p. 117.

114. Patrick Kingsley, 'New Europe: the life of a Polish family', The Guardian, 4 April 2011: theguardian.com/world/2011/apr/04/new-europe-poland-family-life. See also: Maciej Miezian, Nowa Huta: socjalistyczna $w$ formie, fascynujq̨a $w$ treści, Kraków, Bezdroża, 2004.

115. Kinga Pozniak, 'Generations of memory in the "model socialist town" of Nowa Huta', Poland, Focaal, 66, 2013, p. 63-66. 
The organic narratives of Dunaújváros suggest that it is possible to minimise the trauma of Communism by emphasising the national elements in the narratives even in spaces that used to belong to the symbolic spaces of the Communist system such as Sztálinváros, 'the Disneyland of Hungarian socialism'. ${ }^{116}$ So the success of postsocialist cities depends not only on their financial and social reality, but also on finding a way to accommodate their past in keeping with national narratives. Most importantly, however, the success depends on the alignment of the cities' individual histories and stories with the way countries want to be seen: either by rejecting Communism in its entirety (Nowa Huta) or by 'nationalising' it (Dunaújváros). By repositioning their various narratives, societies constantly attempt to construct their 'true' identity, as 'social representation of history or collective memory are narratively constructed'. ${ }^{117}$

116. Ferenc Zsélyi, Istvan András, Mónika Rajcsányi-Molnár, ‘Exegi Mo(nu)mentum - The Media Iconology of Dunaujvaros', in Metamorphosis: Global Dilemmas in Three Acts, Dunaujvaros, Új Mandátum Kiadó, 2013, p. 63.

117. János László, Bea Ehmann, 'Narrative Social Psychology and the Narrative Categorical Content Analysis (NarrCat) in the Study of Social Representations of History', Papers on Social Representations, 22, 2013, p. 3.1, psych.lse.ac.uk/psr/PSR2013/2013_1_3.pdf 